\title{
特集：「知的センシングと知的制御の最新動向」 論文募集のお知らせ
}

掲載予定号：2017年 4 月号

投稿締切り：2016年 5 月 9 日

ゲストエディタ：小林 一行

上記特集の論文を以下の要領で募集いたします，ふるってご投稿ください.

知的センシングと知的制御に関する論文を募集いたします。知的センシング，知的制御の研究は，コンピュー タの小型, 軽量, 高性能化, MEMS センサなどの 普及により, 理論的な段階から実用的な段階へとシフトしつ つあります。従来，実時間処理が不可能であった多くの情報から，知的信号処理，画像処理により新たな知見を 引き出すことが可能になるなど，知的センシングの適用の可能性が広がってきています。また，複数のセンサ， 時系列データ, 経験などから総合的に状況を判断する知的制御は, 安定性の面でも理論的な展開も進みつつあり, 実時間における知的制御が可能となりつつあります.

知的センシングと知的制御の組み合わせは，外界の状況が複雑に变化する環境，いわゆるリアルワールドにお いて, より知的な振る舞いを実現する上で 重要な役割を果たすと期待されています. 本特集号では, 知的セン シング，知的制御に関連する研究，知的センシング，知的制御に関連する応用研究，また，具 体的な適用事例 など，手法，アルゴリズムなどに関する論文を広く募集いたします。

\section{1. 募集分野}

知的制御・知的センシング(ファジィ，ニューロ，強化学習，遺伝アルゴリズム，Deep Learningなど)の理論 的な要素を取り込んでいる研究，知的センシングを用いた信号处理に関する研究，知的画像処理を含んだ画像解 析に関する研究，統計的手法など知的センシングを用いた最適化に関する研究，知的制御，知的センシングのた めのフレームワーク，インターオペラビリティ（ROS，RT-middleware, JAUS) に関連する研究，自律ロボッ トの知的センシングおよび知的制御に関する研究など，幅広い研究分野からの投稿を歓迎いたします.

\section{2. 投稿締め切り}

2016年 5 月 9 日 (月) (必着)

\section{3. 論文の種類}

論文の種類には，「原著論文」，「総説論文」，「実践研究論文」，「ショートノート」があり，非会員の方を含めて どなたでも投稿できます.詳しくは投稿のご案内 (http://www.j-soft.org/journal/toukou/)をご覧ください.また， 投稿時にはそのいずれであるかを明記してください.

\section{4. 提出物および提出方法}

提出物および提出方法につきましては，学会ホームページの「電子投稿・查読システムに関する情報」(http:// www.j-soft.org/journal/e-toko/) をご覧ください.

（*) 投稿規定や著作権規程などは学会ホームページの下にあります. 投稿規定に基づいて投稿原稿を处理いたし ます.

\section{5. 查読プロセス}

通常の査読プロセスに従います。また途中の処理の都合で，本特集号の発刊に間に合わなくなった論文は通常 の論文として他号に掲載される場合があることをあらかじめご承知おきください. 


\section{6. 問い合わせ先}

法政大学理工学部創生科学科 小林 一行

E-mail :ikko@hosei.ac.jp

\section{第 32 回ファジィシステムシンポジウム開催案内}

今年の第 32 回ファジィシステムシンポジゥムは, 自然豊かな歴史のある中核都市・熊本で開催いたします. ファジィ理論をはじめ，知能情報システムに関する講演やイベントを予定しております，会員の皆様からの企画 提案も歓迎いたします。

2004 年の第 20 回以来の九州開催になります. 多数の皆様のご参加を持待ちしております.

なお，詳細は大会ウェブページ (http://fss2016.j-soft.org/)に掲載いたします.

口主 催 : 日本知能情報ファジィ学会 (SOFT)

口共 催 : 国際ファジィシステム学会 (IFSA)

口会 場 : 東海大学熊本キャンパス

干 $862-8652$ 熊本県熊本市東区渡鹿 $9-1-1$

口会 期：2016年 8 月 31 日(水)，9月 1 日(木)，2 日(金)

ロテーマ：次なる半世紀の始まり，ファジィの新たな火をつけろ！FSS in 火の国熊本

ロスケジュール：

2016年 3 月 14 日 (月) : 企画セッション提案申込締切

2016年 5 月 13 日 (金) : 講演申込締切

2016年 6 月 30 日 (木) : 講演原稿送付締切

2016年 7 月 29 日 (金)：事前参加申込締切

ロプログラム : 一般講演, 企画セッション講演(計画型・公募型), ポスター・デモセッション, 特別講演, 招待 講演, 特別企画 (ミニ四駆 $\mathrm{AI}$ 大会), その他

口大会組織

実行委員長 : 佐松 崇史 (東海大学)

実行副委員長 : 島川 学(熊本高等専門学校)

プログラム委員長 : 片上 大輔 (東京工芸大学)

財務委員長 : 大木 真(熊本高等専門学校)

会場担当実行委員 : 藤本 邦昭 (東海大学)

\section{SCIS\&ISIS 2016 開催案内}

会議名：

Joint 8th International Conference on Soft Computing and Intelligent Systems and 17th International Symposium on Advanced Intelligent Systems

主 催：日本知能情報ファジィ学会 $(\mathrm{SOFT})$

協 賛 :

The Korean Institute of Intelligent Systems (KIIS), The International Fuzzy Systems Association (IFSA), IEEE Systems, Man, and Cybernetics Society, IEEE Computational Intelligence Society, North American Fuzzy Information Processing Society (NAFIPS), IEEE SMCS Japan Chapter

後援 (予定) : 北海道, 札幌市, 北海学園大学, 他 学会多数 
会期 : 2016 年 8 月 25 日 (木) 8 月 28 日 (日)

会場：北海学園大学 豊平キャンパス

干 062-8605 北海道札幌市豊平区旭町 4 丁目 1 番 40 号

（札幌市営地下鉄東豊線「学園前」駅 直結）

プログラム (予定) :

招待講演，特別講演，企画セッション，一般セッション，ポスターセッション，バンケット

スケジュール :

2016 年 1 月 22 日 (金) : 企画セッション提案締切

2016年 2 月 15 日 (月)：論文投稿締切

2016年 5 月 1 日 (日) : 查読結果通知

2016 年 6 月 1 日 (水) : 最終原稿締切

大会委員長 $($ 日本側 $)$ ：

山ノ井 高洋(北海学園大学)

ホームページ : http://scis2016.j-soft.org/

問い合わせ：scisisis2016+info@gmail.com

\section{GAT2016 第 1 回ゲーム AI大会 開催案内}

開催期間：2016日 3 月 9 日(水)

会場 : 電気通信大学内 東地区 $\mathrm{C}$ 棟 $/$ 新 $\mathrm{C}$ 棟 $($ 予定 $)$

ゲーム内容：ミニ四駆 $\mathrm{AI}$ ，人狼知能，デジタルカーリング，ターンベース戦略ゲーム，5五将棋等 発表申込：2016日 2 月 15 日 (月)

参加申込 : 各ゲームの詳細は Web 参照

問い合わせ先 : 西野順二 (電気通信大学)

email : nishinojunji@uec.ac.jp

URL : http://minerva.cs.uec.ac.jp/gat_uec/wiki.cgi 


\section{日本知能情報ファジィ学会行事カレンダー（Vol.28-No.1 : 2016年 2月）}

「照会先」の闌に広報用のU R L が掲載されている行事につきましては，それらのホームページにより詳細情報 をご確認ください。

日本知能情報ファジィ学会, 支部, 研究会の主催行事

\begin{tabular}{|c|c|c|c|}
\hline 行 事 名 & 開 催 日 & 開 催 地 & 申込メ切 \\
\hline \multicolumn{4}{|l|}{ 照 会 先 } \\
\hline モバイル学会 & \multirow{2}{*}{ 2016年3月10-11日 } & 産業技術総合研究所つくばセンター & \multirow{2}{*}{ 2015年10月31日 } \\
\hline シンポジゥム「モバイル’16」 & & (茨城県つくば市) & \\
\hline \multicolumn{4}{|c|}{ http://www.mobilergo.com/siteapps/1022/htdocs/?page_id=716 } \\
\hline 計測自動制御学会 & \multirow[b]{2}{*}{ 2016年3月10-11日 } & \multirow{2}{*}{ 室蘭工業大学 (北海道室蘭市) } & \multirow{2}{*}{ 2016年1月8日 } \\
\hline 第 43 回知能システムシンポジウム & & & \\
\hline \multicolumn{4}{|l|}{ http://www.sice.or.jp/org/i-sys/is43/index.html } \\
\hline \multirow{2}{*}{$\begin{array}{l}\text { 日本知能情報ファジィ学会ソフトサイエンス研究部会 } \\
\text { 第 } 26 \text { 回ソフトサイエンス・ワークショップ }\end{array}$} & \multirow{2}{*}{ 2016年3月5-6日 } & \multirow{2}{*}{ 山形大学工学部 (山形県山形市) } & \multirow{2}{*}{ 2012年2月12日 } \\
\hline & & & \\
\hline \multicolumn{4}{|l|}{ http://www.isc.senshu-u.ac.jp//thc0456/nef/softs $2016 . \mathrm{html}$} \\
\hline 日本計算工学会 & \multirow{2}{*}{ 2016年5月 31 日-6月 2 日 } & 朱鷺メッセ 新潟コンベンション & \multirow{2}{*}{ 2016年1月20日 } \\
\hline 第 21 回計算工学講演会 & & センター (新潟県新潟市) & \\
\hline \multicolumn{4}{|l|}{ http://www.jsces.org/koenkai/21/ } \\
\hline 日本機械学会 & \multirow[b]{2}{*}{ 2016年6月8-11日 } & \multirow{2}{*}{$\begin{array}{l}\text { パシフィコ横浜, 大さん橋ホール, } \\
\text { 他 (神奈川県横浜市) }\end{array}$} & \multirow[b]{2}{*}{ 2016年1月29日 } \\
\hline ロボティクス・メカトロニクス講演会 2016 & & & \\
\hline \multicolumn{4}{|l|}{ http://robomech.org/2016/ } \\
\hline 可視化情報学会 & \multirow[b]{2}{*}{ 2016年7月19-20日 } & \multirow{2}{*}{$\begin{array}{l}\text { 工学院大学 新宿キャンパス } \\
\text { (東京都新宿区) }\end{array}$} & \multirow{2}{*}{ 2016年3月11日 } \\
\hline 第 44 回可視化情報シンポジゥム & & & \\
\hline \multicolumn{4}{|l|}{ http://www.visualization.jp/event/detail/symp2016.html } \\
\hline 日本機械学会 & \multirow{3}{*}{ 2016年8月 $23-26$ 日 } & \multirow{3}{*}{$\begin{array}{l}\text { 山口大学常盤キャンパス } \\
\text { (山口県宇部市) }\end{array}$} & \multirow{3}{*}{ 2016年2月 22 日 } \\
\hline Dynamics and adedign Conference 2016 & & & \\
\hline 〜交わりは解を導く〜 & & & \\
\hline \multicolumn{4}{|l|}{ http://www.jsme.or.jp/conference/dmcconf16/ } \\
\hline \multirow{2}{*}{$\begin{array}{l}\text { 電気学会 } \\
\text { 平成 } 28 \text { 年電気学会産業応用部門大会 }\end{array}$} & \multirow{2}{*}{ 2016年8月30-9月 1 日 } & \multirow{2}{*}{$\begin{array}{l}\text { 群馬大学荒巻キャンパス } \\
\text { (群馬県前橋市) }\end{array}$} & \\
\hline & & & 2016年5月13日 \\
\hline http://www.iee.jp/wp-content/uploads/2015/09/Dtai & i_2016_Poster.pdf & & \\
\hline 日本ロボット学会 & 2016年0月7-0口 & 山形大学小白川キャンパス & \\
\hline 第 34 回ロボット学会学術講演会 & 2016年9月7-9日 & (山形県山形市) & 2016年7月13日 \\
\hline http://rsj2016.rsj-web.org/ & & & \\
\hline 可視化情報学会 & & 茨城大学日立キャンパス & \\
\hline 可視化情報全国講演会 (日立 2016) & 2016年10月8-9日 & (茨城県日立市) & 2016年6月3日 \\
\hline tachi.htm & & & \\
\hline
\end{tabular}


日本知能情報ファジィ学会行事カレンダー（Vol.28-No.1：2016年 2月）

\begin{tabular}{|c|c|c|c|}
\hline \multicolumn{4}{|l|}{ 照 会 先 } \\
\hline $\begin{array}{l}\text { DCC } 2016 \\
2016 \text { Data Compression Conference (DCC) }\end{array}$ & 2016 年 3 月 30 日 -4 月 1 日 & Snowbird, UT, USA & 2015年11月 2 日 \\
\hline \multicolumn{4}{|l|}{ http://www.cs.brandeis.edu/ dcc/ } \\
\hline $\begin{array}{l}\text { WCCI } 2016 \\
2016 \text { IEEE World Congress on Computational } \\
\text { Intelligence (WCCI) }\end{array}$ & 2016年7月 25-29日 & Vancouver, Canada & 2016年1月15日 \\
\hline \multicolumn{4}{|l|}{ http://www.wcci2016.org/ } \\
\hline $\begin{array}{l}\text { ICCOINS } 2016 \\
2016 \text { 3rd International Conference on Computer and } \\
\text { Information Sciences (ICCOINS) }\end{array}$ & 2016年8月15-17日 & Kuala Lumpur, Malaysia & 2016年1月31日 \\
\hline \multicolumn{4}{|l|}{ http://usite.utp.edu.my/iccoins2016/\#/SitePages/Home.aspx } \\
\hline $\begin{array}{l}\text { IFAC HMS } 2016 \\
\text { The 13th IFAC/IFIP/IFORS/IEA Symposium on } \\
\text { Analysis, Design, and Evaluation of Human-Machine } \\
\text { Systems (IFAC HMS) }\end{array}$ & 2016年8月 30 日-9月 2 日 & $\begin{array}{l}\text { ザソウドウ 東山 京都 } \\
\text { (京都府京都市) }\end{array}$ & 2015年11月21日 \\
\hline \multicolumn{4}{|c|}{ http://www.syn.me.kyoto-u.ac.jp/IFAC HMS 2016/index.html } \\
\hline $\begin{array}{l}\text { IS } 2016 \\
2016 \text { IEEE 8th International Conference on Intelligent } \\
\text { Systems (IS) }\end{array}$ & 2016年9月4-6日 & Sofia, Bulgaria & 2015年12月 20 日 \\
\hline \multicolumn{4}{|l|}{ http://www.ieee-is.org/ } \\
\hline $\begin{array}{l}\text { MDAI } 2016 \\
\text { The 13th International Conference on Modeling } \\
\text { Decisions for Artificial Intelligence }\end{array}$ & 2016年9月19-21日 & Sant Julia de Loria, Andorra & 2016年3月 24 日 \\
\hline \multicolumn{4}{|l|}{ http://www.mdai.cat/mdai2016/ } \\
\hline $\begin{array}{l}\text { CIG } 2016 \\
2016 \text { IEEE Conference on Computational Intelligence } \\
\text { and Games (CIG) }\end{array}$ & 2016年9月21-23日 & Fira, Greece & 2016年4月30日 \\
\hline \multicolumn{4}{|l|}{ http://cig16.image.ece.ntua.gr/ } \\
\hline $\begin{array}{l}\text { 日本神経回路学会 } \\
\text { The 23th International Conference on Neural } \\
\text { Information Processing (ICONIPP201) }\end{array}$ & 2016年10月17-21日 & $\begin{array}{l}\text { 京都大学時計台記念館 } \\
\text { (京都府京都市) }\end{array}$ & 2016 年4月 24 日 \\
\hline \multicolumn{4}{|l|}{ http://www.iconip2016.org/index.html } \\
\hline $\begin{array}{l}\text { ISITA } 2016 \\
2016 \text { International Symposium on Information Theory } \\
\text { and Its Applications (ISITA) } \\
\text { http://www.isita.ieice.org/2016/ }\end{array}$ & 2016年10月30-11月 2 日 & Monterey, California, USA & 2016年4月7日 \\
\hline $\begin{array}{l}\text { SSCI } 2016 \\
2016 \text { IEEE Symposium Series on Computational } \\
\text { Intelligence (SSCI) }\end{array}$ & 2016年12月6-9日 & Athens, Greece & 2016年7月18日 \\
\hline http://ssci2016.cs.surrey.ac.uk/ & & & \\
\hline $\begin{array}{l}\text { FUZZ- IEEE } 2017 \\
2017 \text { IEEE International Conference on Fuzzy } \\
\text { Systems (FUZZ-IEEE) }\end{array}$ & 2017年7月9-12日 & Naples, Italy & 2017年1月25日 \\
\hline
\end{tabular}

